\title{
Influence of nutrition on oral cavity tissues, which determines the correct use of dentures in the elderly population
}

\section{Wpływ odżywiania na stan tkanek jamy ustnej warunkujących prawidłowe użytkowanie osiadających uzupełnień protetycznych $w$ populacji osób starszych}

\author{
Natalia Wiśniewska1, Adam Kolenda ${ }^{2}$, Elżbieta Mierzwińska-Nastalska ${ }^{2}$ \\ ${ }^{1}$ Studenckie Koło Naukowe przy Katedrze Protetyki Stomatologicznej, Warszawski Uniwersytet Medyczny \\ Students' Research Group at the Chair of Prosthodontics, Medical University of Warsaw \\ ${ }^{2}$ Katedra Protetyki Stomatologicznej, Warszawski Uniwersytet Medyczny \\ Chair of Prosthodontics, Medical University of Warsaw \\ Kierownik: prof. dr hab. n. med. Elizbieta Mierzwińska-Nastalska
}

KEY WORDS:

nutrition, vitamins, age, dentures

\section{Summary}

Aging is an unavoidable phenomenon, however, despite of age-related deterioration, the length of life is increasing systematically. ${ }^{1}$ Poland has been placed in the top thirty countries demographically old for years. Between 1950-2005 the share of the population aged over 64 years old grew more than twice. ${ }^{2}$ This results in a need to update the knowledge about physiology and changes in the body of an elderly in order to be able to predict the direction of atrophic changes and to provide proper prosthetic treatment.

A proper nutrition, both quantitatively and qualitatively, determines the health of the entire body and a proper condition of the oral cavity tissues. Based on the selected literature, the article presents a view on the impact of diet components on oral cavity tissue health with a particular emphasis on the elderly population using removable prostheses. Age-related changes in the oral cavity cause a progressive tooth loss
HASŁA INDEKSOWE:

odżywianie, witaminy, starość, osiadające uzupełnienia protetyczne

\section{Streszczenie}

Starzenie się organizmu jest zjawiskiem nieuniknionym, jednak dtugość życia systematycznie się wydtuża pomimo pogarszajacego się z wiekiem stanu zdrowia. ${ }^{1}$ Polska od lat znajduje sie $w$ pierwszej trzydziestce krajów demograficznie starych. W okresie 1950-2005 udziat ludności w wieku powyżej 64 lat wzróst ponad dwa razy. ${ }^{2}$ Skutkuje to potrzeba aktualizacji wiedzy na temat fizjologii i zmian zachodzacych w organizmie osób starszych, aby móc przewidzieć kierunek atrofii $i$ wdrożyć właściwa terapię protetyczna.

Prawidłowe odżywianie zarówno pod względem ilościowym, jak i jakościowym warunkuje zdrowie catego organizmu, a zatem także stan tkanek jamy ustnej. Na podstawie wybranego piśmiennictwa przedstawiono poglad dotyczacy wplywu składników diety na stan jamy ustnej, ze szczególnym uwzględnieniem populacji osób starszych uzytkujacych osiadajace uzupetnienia protetyczne. Zmiany $w$ obrębie jamy ustnej 
and as a consequence a need for using dental prostheses. Prosthetic dentures transfer the chewing forces to the bone through the mucous membrane. The health of these tissues is necessary for the proper stabilization and retention of the dentures, chewing efficiency and allows to use a balanced, nutritious diet.

\section{Introduction}

Ingestion of food in the correct quantity and composition is necessary for human health. This is particularly true of the elderly population often exposed to shortages due to, among others, the reduced efficiency of mastication caused by the loss of teeth - an important malnutrition factor. It is associated with a reduced consumption of vegetables, fruit and fibre, and also with a low concentration of vitamin $\mathrm{C}$ in serum. Toothless patients using removable denb tures have a better nutritional status in comparison with those without any prosthetic resf torations. $^{3}$

Changes in the oral cavity of the elderly are atrophic in character. With age, the amount of organic components in the enamel decreases in favour of the inorganic ones. The deposition of secondary dentine leads to the obliteration of the pulp chamber, whereby the pulp becomes less vascularised. A progressive generalized periodontal loss of alveolar bone is observed, the mucous membrane loses its elasticity and becomes susceptible to damage. The salivary glands are getting more fibrotic and fatter. This results in the change of quality and quantity of secreted saliva. ${ }^{4}$ All of these factors result in a gradual loss of teeth, which translates into the need to use dentures and may have an impact on the comfort of their use. Dentures transfer the chewing forces directly to the bone through the mucous membrane, therefore, the comfort pojawiajace się z wiekiem powoduja postępujaca utrate zębów, a w konsekwencji konieczność uzytkowania protez zębowych. Uzupetniania protetyczne osiadajace przenosza sity żucia na kość poprzez błonę śluzowa. Zdrowie tych tkanek jest niezbędne dla uzyskania prawidtowej stabilizacji i retencji protez, wydolności żucia oraz umożliwia stosowanie zbilansowanej, petnowartościowej diety.

\section{Wprowadzenie}

Dostarczanie pokarmu w prawidłowej ilości i składzie jest niezbędne dla zachowania zdrowia człowieka. Dotyczy to szczególnie populacji osób starszych, często narażonej na niedobory $\mathrm{z}$ powodu $\mathrm{m}$. in. zmniejszonej wydolności żucia wywołanej utratą własnych zębów. Wykazano, iż bezzębie jest istotnym czynnikiem niedożywienia, łączy się ze zmniejszoną konsumpcją warzyw, owoców i błonnika, a także niższym stężeniem witaminy $\mathrm{C}$ w surowicy. Pacjentów bezzębnych użytkujących protezy ruchome charakteryzuje lepszy stan odżywienia $\mathrm{w}$ porównaniu $\mathrm{z}$ osobami bezzębnymi bez uzupełnień protetycznych. ${ }^{3}$

Zmiany w obrębie jamy ustnej osób starszych mają charakter atroficzny. Z wiekiem zmniejsza się ilość składników organicznych w szkliwie na korzyść nieorganicznych. Odkładanie zębiny wtórnej prowadzi do obliteracji komory zęba, przez co miazga staje się słabiej unaczyniona. Obserwuje się postępujący uogólniony starczy zanik przyzębia z zanikiem kości wyrostka zębodołowego włącznie, błona śluzowa traci swoją elastyczność i staje się podatna na uszkodzenia. Gruczoły ślinowe ulegają zwłóknieniu i stłuszczeniu. Powoduje to zmianę jakości i ilości wydzielanej śliny. ${ }^{4}$ Wszystkie wymienione czynniki skutkują stopniową utratą zębów przekładającą się na potrzebę użytkowania protez zębowych oraz istotnie wpływają na komfort ich 
and the capability of their use by the patient depends on the quality and health of these tissues. What is more, healthy periodontal tissues give a chance to enjoy a balanced diet. ${ }^{5}$ Denture weara ers often modify their diets, resigning from many dietary products and, as a consequence, their diet becomes poorer. ${ }^{3,6,7}$ It has been estimated that the incidence of malnutrition in Europe is up to $15 \%$ in the elderly living secluded lives. ${ }^{3}$

Deficient states belong to a group of diseases causing the greatest ailments in the population of seniors. ${ }^{8}$ Nutritional deficiencies are divided into quantitative and qualitative. Nutrition of the elderly in particular should contain foods rich in protein, carbohydrates, fats, vitamins A, B, C, D, calcium and fibre..$^{5}$ Fig. 1 shows the current pyramid of human nutrition, which illustrates the principles of healthy nutrition. Products located at the base of the pyramid should constitute the basis of a daily diet.

Daily calorie requirements in population of over 66-year-olds vary from 1500 to $3250 \mathrm{kcal} .{ }^{9}$ Too low caloric intake of food leads to gradual wasting away of the body that, in a longer perspective, may be a cause of emaciation. Otherwise, its excess results in overweight or obesity, which is a risk factor in many systemic diseases, including diabetes. ${ }^{10}$ Studies have shown that unbalanced level of glucose in the blood in patients with type 2 diabetes is a factor of multiple increase of an alveolar bone loss in comparison with healthy people. ${ }^{11}$ Moreover, the association between diabetes and the incidence of xerostomia was noted. ${ }^{12}$ This causes deterioration of denture retention and stability, making it difficult to adapt to this type of ress toration.

Nutrients are substances delivered to the body with food. These include proteins, fats, carbohydrates, vitamins, minerals and water. They have three basic functions in the body: building, energy providing and regulating. The most important part of the building elements are proteins. Carbohydrates and fats provide użytkowania. Protezy osiadające przenoszą siły żucia bezpośrednio na kość za pośrednictwem błony śluzowej, zatem od jakości i zdrowia tych tkanek zależy zarówno wygoda jak i możliwość ich użytkowania przez pacjenta. Ponadto zdrowe tkanki przyzębia dają szansę stosowania zbilansowanej diety. ${ }^{5}$ Osoby użytkujące protezy często modyfikują dietę, rezygnując $\mathrm{z}$ wielu produktów, przez co ich dieta staje się niepełnowartościowa. 3,6,7 Oszacowano, że częstość występowania niedożywienia w Europie wynosi do 15\% u osób starszych żyjących samodzielnie. ${ }^{3}$

Stany niedoborowe należą do grupy chorób sprawiających największe dolegliwości w populacji seniorów. ${ }^{8}$ Niedobory żywieniowe dzielą się na niedobory ilościowe i jakościowe. Pożywienie pacjentów starszych powinno zawierać przede wszystkim pokarmy bogate w białko, węglowodany, tłuszcze, witaminy A, B, C, D, wapń i błonnik..$^{5}$ Na rycinie 1 przedstawiono aktualną piramidę żywienia człowieka, która ilustruje zasady zdrowego odżywiania. Produkty znajdujące się u podstawy piramidy powinny być podstawą codziennej diety.

Dzienne zapotrzebowanie kaloryczne w populacji osób powyżej 66 roku życia waha się od 1500 do 3250 kcal. ${ }^{9}$ Zbyt mała kaloryczność pokarmu prowadzi do osłabienia organizmu, a w dłuższej perspektywie wyniszczenia. Nadmiar kalorii może skutkować nadwagą bądź otyłością, która jest czynnikiem ryzyka wielu chorób ogólnoustrojowych, w tym cukrzycy. ${ }^{10}$ Badania wykazały, że niewyrównany poziom glikemii we krwi u osób z cukrzycą typu 2, wielokrotnie zwiększa ryzyko progresji utraty kości wyrostka zębodołowego w porównaniu z osobami zdrowymi. ${ }^{11}$ Ponadto zauważono związek między zachorowaniem na cukrzycę a występowaniem kserostomii. ${ }^{12}$ Powoduje to pogorszenie stabilizacji i retencji protez zębowych, co utrudnia adaptację pacjenta do tego typu uzupełnień. 


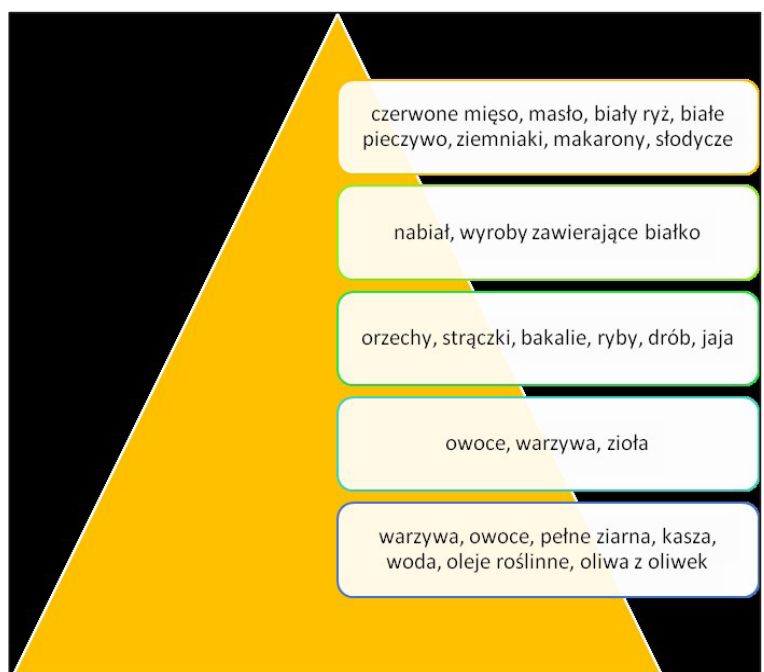

Fig. 1. Pyramid of human nutrition (based on: Calyniuk B, Grochowska-Niedworok E, Bialek A, Czech N, Kukielczak A: Piramida żywienia-wczoraj i dziś. Probl Hig Epidemiol 2011; 92, 1, 20-24).

Ryc. 1. Piramida żywienia człowieka (na podstawie: Calyniuk B, Grochowska-Niedworok E, Bialek A, Czech N, Kukielczak A: Piramida żywienia-wczoraj i dziś. Probl Hig Epidemiol 2011; 92, 1, 20-24).

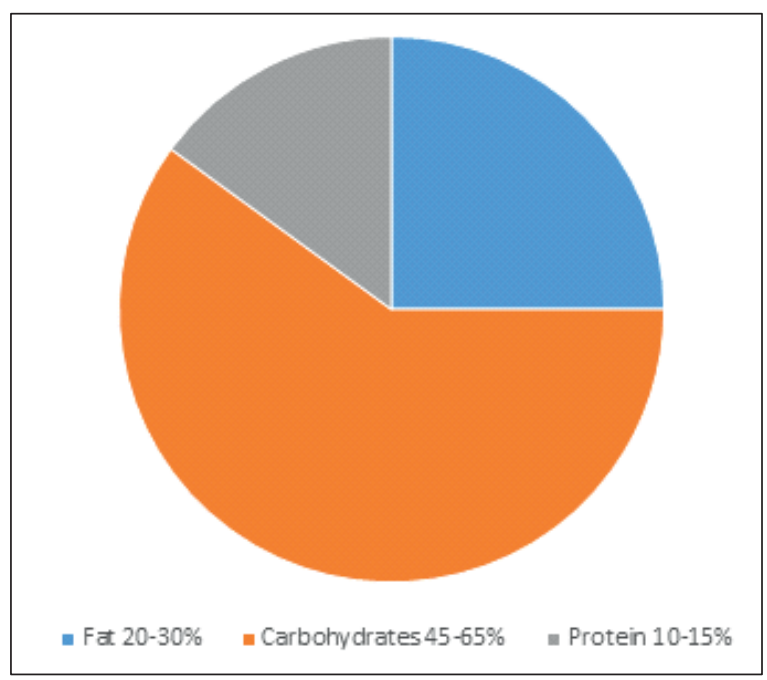

Fig. 2. WHO recommendations on the composition of adult diet (based on: Joint WHO/FAO Expert Consultation on Diet Nutrition and the Prevention of Chronic Diseases, Diet, Nutrition and Prevention of Chronic Diseases, Publ Health Nutr 2004; 7, 1).

Ryc. 2. Zalecenia WHO dotyczace sktadu diety dla dorostego czlowieka (na podstawie: Joint WHO/ FAO Expert Consultation on Diet Nutrition and the Prevention of Chronic Diseases, Diet, Nutrition and Prevention of Chronic Diseases, Publ Health Nutr 2004; 7, 1).
Składniki odżywcze są substancjami dostarczanymi do organizmu przez pokarm. Należą do nich białka, tłuszcze, węglowodany, witaminy, sole mineralne oraz woda. Pełnią one w organizmie trzy podstawowe funkcje tj. budulcową, energetyczną i regulującą. Najważniejszym elementem budulcowym są białka. Węglowodany i tłuszcze dostarczają energii, natomiast witaminy regulują ważne dla metabolizmu człowieka procesy. Na rycinie 2 przedstawiono zalecenia dotyczące procentowego składu prawidłowej diety.

Białka są niezbędne do prawidłowego przebiegu reakcji immunologicznych typu komórkowego i humoralnego, tworzą elementy kurczliwe mięśni i uczestniczą $\mathrm{w}$ procesie remodelingu kości. U osób młodych obserwuje się mechanizm adaptacyjny w postaci wzrostu wchłaniania wapnia z przewodu pokarmowego na skutek spadku podaży tego pierwiastka w diecie. W późniejszym wieku mechanizm ten staje się niewystarczający dla utrzymania optymalnego bilansu wapnia. ${ }^{13} \mathrm{~W}$ związku z tym u osób w podeszłym wieku częściej obserwuje się niedobory tego składnika objawiające się osłabieniem siły mięśniowej, zmniejszoną możliwością regeneracji błony śluzowej i postępującą osteoporozą. ${ }^{3,14}$ Nadmierne siły działające na kość spowodowane uciskiem protezy zębowej powodują jej zanik. Efektem tych czynników jest zmniejszenie wydolności żucia i odstąpienie od spożywania pokarmów twardych, tak ważnych z punktu widzenia prawidłowej perystaltyki jelit, a tym samym ich prawidłowej funkcji polegającej na odpowiednim wchłanianiu spożywanych składników odżywczych. ${ }^{15}$

Kolejnymi istotnymi składnikami diety są tłuszcze, w tym cholesterol. Ich nadmierne spożycie prowadzi do odkładania lipidów w ścianach naczyń krwionośnych w postaci blaszek miażdżycowych zmniejszających przepływ krwi przez naczynia i wywołujących ogniska miejscowego niedokrwienia. $\mathrm{Na}$ 
energy, while the vitamins regulate human metabolism processes. Figure 2 shows the percentn age of correct diet composition.

Proteins are necessary for the proper course of cellular and humoral immune reactions; they create muscle contractile elements and participate in the process of bone remodeling. Adolescents have an adaptive mechanism in the form of increased absorption of calcium from the gastrointestinal tract as a result of the decline in the supply of that element in the diet. Later, this mechanism becomes insuffii cient to maintain optimal calcium balance. ${ }^{13}$ Therefore, elderly people are more likely to have deficiencies of this dietary component manifested by muscle weakness, reduced mucosal regeneration and progressive osteoporosis. ${ }^{3,14}$ Excessive forces acting on the bone due to the pressure of the dental prosthesis cause its atrophy. In effect, patients experience reduced chewing capacity and exclusion of hard foods that are so important for proper intestinal peristalsis and thus intestinal function of proper abt sorption of nutrients. ${ }^{15}$

Another important component of the diet is fats, including cholesterol. Their excessive consumption leads to the deposition of lipids in the walls of blood vessels in the form of atherosclee rotic plaques that reduce blood flow through the vessels and cause the outbreak of local ischemia. As a result of obstruction of capillaries, physiological and post-traumatic regeneration of the oral mucosa is very difficult. Wounds do not heal for a long time, infections are spread more easily. This is particularly important for the users of dentures when there are some sharp edges on the denture plate, or when the prosthesis clip is inappropriately designed or made. ${ }^{16}$ It has been proven that the excessive consumption of saturated fatty acids causes the progression of periodontal diseases. ${ }^{17}$ Low quantity of fat in the diet results in the deficiency of fatsoluble vitamins (A, D, E, K).

One of the criteria in the diagnosis of a skutek niedrożności naczyń włosowatych, fizjologiczna jak i pourazowa regeneracja błony śluzowej jamy ustnej jest utrudniona. Uszkodzona błona śluzowa goi się dłużej i dochodzi do nadkażeń bakteryjnych i grzybiczych. Jest to szczególnie ważne dla użytkowników protez osiadających w przypadku występowania ostrych brzegów w obrębie płyty uzupełnienia bądź nieprawidłowo zaprojektowanej lub wykonanej klamry. ${ }^{16}$ Udowodniono, że spożywanie nadmiaru nasyconych kwasów tłuszczowych powoduje progresję choroby przyzębia. ${ }^{17}$ Niska zawartość tłuszczu w diecie skutkuje z kolei niedoborem witamin rozpuszczalnych w tłuszczach (A, D, E, K).

Jednym z kryteriów stanowiącym o rozpoznaniu zespołu metabolicznego, nazywanego także zespołem insulinooporności, jest glikemia na czczo $\geq 100 \mathrm{mg} / \mathrm{dl}$ lub obecność cukrzycy typu 2. ${ }^{18}$ Dowiedziono, iż osoby spożywające nadmierne ilości cukru mają większe ryzyko rozwinięcia zespołu metabolicznego. ${ }^{19}$ Hiperinsulinemia sprzyja rozwojowi insulinooporności i w efekcie prowadzi do rozwoju cukrzycy typu 2, która jest czynnikiem ryzyka dyslipidemii i choroby niedokrwiennej serca wpływających na stan przyzębia jamy ustnej. ${ }^{20}$ Ponadto, nadmierne spożycie węglowodanów prostych sprzyja odkładaniu płytki protez, która nieusunięta staje się pożywką dla bakterii oraz grzybów drożdżopodobnych w efekcie czego u pacjentów użytkujących protezy osiadające częściej obserwuje się rozwój stomatopatii protetycznych, utrudnione gojenie spowodowane nadkażeniem drobnych ran i halitozę. ${ }^{21,22,23}$

Niedobór witaminy B (w szczególności witaminy $\mathrm{B}_{12}$ ) może prowadzić do wystąpienia zespołu pieczenia jamy ustnej (Burning Mouth Syndrome, BMS), zapalenia kątów ust, glossodynii i suchości błony śluzowej. ${ }^{8}$ Stomatodynia i glossodynia są określane jako uczucie palenia w obrębie jamy ustnej przy 
metabolic syndrome also known as insulin-resistance syndrome, is the fasting blood glucose $\geq 100 \mathrm{mg} / \mathrm{dl}$, or the presence of type 2 diabetes. ${ }^{18}$ It has been shown that people who consume excessive amounts of sugar, have a higher risk of developing metabolic syndrome. ${ }^{19}$ Hyperinsulinemia promotes the development of insulin resistance and consequently leads to the development of type 2 diabetes, which is a risk factor for dyslipidaemia and ischaemic heart disease affecting the periodontal status of the oral cavity. ${ }^{20}$ In addition, the excessive consumption of simple carbohydrates promotes the deposition of a prosthetic plaque which, if not removed, becomes a breeding ground for bacteria and yeast-like fungi. In consequence, denture wearers are more likely to develop prosthetic stomatopathy. What is more, healing of minor wounds is impaired due to infections and halitosis may be observed. ${ }^{21-23}$

The deficiency of vitamin B (in particular vitamin $B_{12}$ ) can lead to the Burning Mouth Syndrome (BMS), angular cheilitis, glossodynia and dry mucosa. ${ }^{8}$ Stomatopyrosis and glossodynia are referred to as an oral burning sensation in the absence of pathological changes on the clinical examination, appearing without any obvious reason. Ailments occur, among other, on the hard palate, which in the case of dentures is covered with an acrylic plate. ${ }^{24,25}$ Patients may mistakenly believe that burning is caused by the use of a prosthesis, and use it irregularly. The BMS can increase the feeling of having foreign bodies in the mouth, which further impedes adaptation, especially in the first period of using new prosthetic restorations. ${ }^{24}$ Dry mouth can adversely affect the stability and retention of the prosthesis. Angular cheilitis associated with incorrectly assessed occlusion height in the clinical process of making prostheses may necessitate additional medical consultation. This builds up the patient's belief that prosthetic treatment was performed improperly, discouraging them braku zmian patologicznych w badaniu klinicznym, pojawiające się bez uchwytnej przyczyny. Dolegliwości występują między innymi na podniebieniu twardym, które w przypadku protez osiadających jest pokryte akrylową płytą. ${ }^{24,25}$ Pacjent może błędnie sądzić, iż pieczenie jest spowodowane użytkowaniem protezy przez co korzysta z niej nieregularnie. Zespół pieczenia jamy ustnej (BMS) może potęgować uczucie ciała obcego w jamie ustnej, co dodatkowo utrudnia adaptację, szczególnie w pierwszym okresie od otrzymania nowych uzupełnień protetycznych. ${ }^{24}$ Suchość jamy ustnej niekorzystnie wpływa na stabilizację i retencję protez. Zapalenie kątów ust powiązane $\mathrm{z}$ nieprawidłowo ustaloną wysokością zwarcia $w$ procesie wykonawstwa klinicznego protez osiadających może być przyczyną dodatkowych wizyt u stomatologa. Buduje to u pacjenta przekonanie o nieprawidłowym wykonaniu uzupełnień protetycznych i zniechęca do ich regularnego użytkowania. ${ }^{14}$ Niedobór kwasu foliowego i żelaza nasila wyżej opisane objawy.

Witamina $\mathrm{C}$ jest niezbędna do prawidłowej biosyntezy kolagenu. Wraz z witaminą E kieruje ona aktywnością fagocytów w czasie infekcji. Jej niedobór skutkuje wzrostem zapadalności na choroby dziąseł i przyzębia, powoduje niedokrwistość przez zmniejszenie absorpcji żelaza w jelitach oraz zmiany w kościach i chrząstkach stawowych. ${ }^{26,} 27$ Spadek stężenia witaminy $\mathrm{C}$ w osoczu skutkuje obniżeniem progu wrażliwości na ucisk protezy i dolegliwości bólowe w trakcie jej użytkowania oraz sprzyja zwiększonej resorpcji kości.

Podobne dolegliwości związane z przenoszeniem sił żucia na podłoże może wywołać niedobór witaminy A, która umożliwia zachowanie ciągłości błony śluzowej, ma działanie antyoksydacyjne, przeciwzapalne i antyproliferacyjne. ${ }^{28}$ Jej niedobór obserwuje się w postaci nadmiernego rogowacenia błony śluzowej jamy ustnej. 
from wearing dentures on a regular basis. ${ }^{14}$ Deficiency of folic acid and iron increases the symptoms described above.

Vitamin C is essential for proper biosynthesis of collagen. Together with vitamin E, it regulates phagocytic activity during infection. Its deficiency results in an increased incidence of gum disease and periodontitis, causes anaemia by decreasing iron absorption in the intestine, and produces changes in bone and joint cartilage. ${ }^{26,27}$ The decrease in the concentration of vitamin $\mathrm{C}$ in plasma reduces the threshold sensitivity for the pressure of prostheses and causes pain. It promotes increased bone resorption.

Vitamin A allows mucosal continuity and has anti-oxidant, anti-inflammatory and antiproliferative effects. Its deficiency may cause ailments associated with the transfer of chewing forces onto the oral mucosa, ${ }^{28}$ and is observed in the form of excessive keratosis of the oral mucosa.

Vitamin D is the so-called sunshine vitamin. It is produced as a result of exposure to sunlight. ${ }^{6}$ Poland is located in a latitude with low intensity of solar radiation. Southern and Southeastern Poland have the largest areas of sunshine concentration. Pomerania is the region where the number of sunny hours is the smallest. ${ }^{29}$ It may lead to deficiency of vitamin $\mathrm{D}$ in the body. Age is also a factor limiting its synthesis. There is a decrease in the concentration of provitamin $\mathrm{D}$ in the skin by up to $75 \%$ after the age of 70 years. ${ }^{30}$ Anuszewska claims that the need for vitamin $\mathrm{D}$ is decreased up to a certain age, which is associated with a more varied diet and increased exposure to sunlight. ${ }^{31}$ Peczowski et al. and Buczkowski et al. recommend an oral dose of vitamin $\mathrm{D}_{3}$ for seniors of 800-2000 IU per day, depending on the body weight, from October to March or throughout the year, due to reduced effectiveness of the skin synthesis of vitamin D. ${ }^{32,33}$ Studies have confirmed the positive effect of
Witamina D to tzw. „witamina promieni słonecznych". Zostaje wytworzona w wyniku ekspozycji na światło słoneczne. ${ }^{6}$ Polska jest położona na szerokości geograficznej objętej niskim natężeniem promieniowania słonecznego. Największe obszary koncentracji usłonecznienia to Polska południowa i południowo-wschodnia. Na Pomorzu ilość godzin słonecznych jest najmniejsza. ${ }^{29}$ Sprzyja to niedoborom witaminy D w organizmie. Wiek także stanowi czynnik ograniczający jej syntezę. U osób po 70 r.ż. obserwuje się zmniejszenie stężenia prowitaminy $\mathrm{D}$ w skórze nawet o $75 \% .{ }^{30}$ Anuszewska dowodzi, iż zapotrzebowanie na witaminę D maleje do pewnego wieku, co jest związane z bardziej urozmaiconą dietą i zwiększoną ekspozycją na światło słoneczne. ${ }^{31}$ Natomiast Ptudowski i wsp. oraz Buczkowski i wsp. rekomendują doustną dawką witaminy $\mathrm{D}_{3}$ dla seniorów w wysokości 800-2000 j.m./dobę, zależnie od masy ciała, od października do marca lub przez cały rok, ze względu na obniżoną efektywność skórnej syntezy witaminy D. ${ }^{32,33}$ Badania potwierdziły pozytywny wpływ podawania witaminy $\mathrm{D}_{3} \mathrm{w}$ przypadkach chorób przewlekłych. Zaobserwowano także obniżenie umieralności na nowotwory. ${ }^{31}$ Zapobiega ona osteoporozie (w tym zanikowi kości wyrostka zębodołowego), na którą jest szczególnie narażona populacja osób starszych, zmniejsza ryzyko chorób układu krążenia, reguluje gospodarkę wapniowo-fosforanową. Wydolność żucia wpływa na stopień aktywności fizycznej osób starszych. ${ }^{34}$ Właściwie wykonane protezy, którymi pacjent potrafi się posługiwać zwiększają czas przebywania pacjenta poza domem- na świeżym powietrzu, a więc i jego zasoby w witaminę D. U osób, u których niemożliwe jest przebywanie w świetle promieni słonecznych powinno się rozważyć suplementację tą witaminą. Należy zaznaczyć, iż badania potwierdzają synergistyczny wpływ witamin $\mathrm{z}$ grupy $\mathrm{K}$ i D na niektóre procesy 
vitamin $\mathrm{D}_{3}$ administration in chronic diseases. Lower cancer mortality rate has also been observed. ${ }^{31}$ It prevents osteoporosis (including alveolar bone loss), which is a problem in the elderly population, reduces the risk of cardiovascular disease, regulates the calcium-phosphate distribution. Chewing ability affects the degree of physical activity of the elderly. ${ }^{34}$ Properly constructed prostheses that the patient is able to use increase the time of the patient's outdoor activities and thus patient's vitamin D level. In those not exposed to sunlight, supplementation with this vitamin should be considered. It should be noted that the studies confirm the synergistic effect of vitamin $\mathrm{K}$ and $\mathrm{D}$ on some metabolic processes. ${ }^{35}$ If the patient uses vita$\min \mathrm{D}_{3}$ alone, there is a possibility that calcium will deposit in the kidneys, arteries (which can lead to heart attacks) and other body organs. Vitamin $\mathrm{K}_{2}$ directs calcium to the bone and removes its excess from other organs such as blood vessels. ${ }^{36}$

The health status of the elderly often requires the use of medicines in treatment of systemic diseases. It has been confirmed that calcium, an essential element for proper bone mineralization, is involved in numerous drug interactions (chemotherapeutics, antibiotics), creating the non-soluble complexes. This results in decrease in their absorption and prolongs the duration of disease. Therefore, a two-hour interval between the consumption of calcium-rich foods and the intake of the above-mentioned drugs is recommended. ${ }^{37}$ With age, as a result of progressive tooth loss and indications for treatment with removable dentures, the loss of alveolar bone is progressing. Calcium deficiency leads to atrophy, worsened stabilization and retention of acrylic dentures.

The consumption of fibre reduces the postprandial glucose level in the blood and cholesterol levels. Fibre improves the intestinal transit and, as a result, it supports the effectiveness of absorption of nutrients in the gastrointestinal metaboliczne. ${ }^{35}$ Stosując samodzielną suplementację witaminy $\mathrm{D}_{3}$ istnieje niebezpieczeństwo odkładania wapnia w nerkach, tętnicach (może prowadzić do zawału serca) i innych narządach ciała. Witamina K2 wpływa na osadzanie się wapnia w kościach i usuwa jego nadmiar z innych narządów oraz układu krwionośnego. ${ }^{36}$

Stan zdrowia osób starszych wymaga często stosowania leków w terapii chorób ogólnoustrojowych. Potwierdzono, że wapń, pierwiastek niezbędny dla prawidłowej mineralizacji kości, wchodzi w liczne interakcje z lekami (chemioterapeutyki, antybiotyki), tworząc w połączeniu z nimi nierozpuszczalne w wodzie kompleksy. Skutkuje to zmniejszeniem ich wchłaniania i wydłuża czas trwania choroby. Zaleca się zatem dwugodzinny odstęp między spożyciem pokarmów bogatych w wapń a przyjęciem wyżej wymienionych preparatów. ${ }^{37} \mathrm{Z}$ wiekiem, na skutek postępującej utraty zębów i wskazań do leczenia z zastosowaniem protez osiadających, wyrostek zębodołowy ulega progresywnemu zanikowi. Niedobór wapnia sprzyja temu procesowi, pogarszając stabilizację i retencję protez akrylowych.

Spożycie błonnika wpływa na obniżenie poposiłkowego stężenia glukozy we krwi i redukcje poziom cholesterolu. Poprawia pasaż jelitowy, tym samym wspierając wydajne wchłanianie składników odżywczych w przewodzie pokarmowym. Zwiększa objętość stolca i niweluje zaparcia, często zgłaszane przez seniorów. ${ }^{15}$ Dzięki probiotycznemu działaniu zmniejsza częstotliwość występowania biegunek redukując możliwość odwodnienia - problemu wieku podeszłego. ${ }^{38,39} \mathrm{~W}$ procesie starzenia się zawartość wody w organizmie spada. Spożycie błonnika wpływa korzystnie na nawodnienie oraz jest ściśle związane z ilością i jakością śliny wydzielanej przez ślinianki, która ma wpływ na komfort użytkowania ruchomych protez zębowych. 
tract. It increases the volume of stool and eliminates constipation that is so often reported by seniors. ${ }^{15}$ Thanks to its probiotic action, it reduces the frequency of diarrhoea, thus decreasing the possibility of dehydration - the problem of the elderly. ${ }^{38,39}$ In the aging process the body water content decreases. Consumption of fiber has a beneficial effect on hydration, and is closely related to the amount and quality of saliva secreted by the salivary glands, which affects the comfort of wearing removable dental prostheses.

\section{Summary}

In the elderly, the intake of nutrients decreases. This is due to the progressive loss of teeth and the use of prosthetic restorations, which older patients sometimes find difficult to adapt to. Denture wearers often modify, or limit, the choice of food. ${ }^{40}$ The local and systemic effects of eating disorders can significantly reduce the patient's quality of life. In order to eliminate nutritional deficiencies in the population of the elderly, education is necessary as well as provision of easy to understand dietary recommendations. The elderly comprise a group of people who require special dental care and appropriate motivation. Taking dietary history of seniors seems to be an important element of medical diagnostics. In addition, it should be emphasized that oral tissues are often the first in which pathological changes are observed in the course of systemic diseases..$^{41}$ Dental practitioners may be the first to notice them. Dietary improvement may impact the patient's better adaptation to removable prostheses, which will significantly increase their life comfort.

\section{Podsumowanie}

W wieku podeszłym spożycie składników odżywczych maleje. Sprzyja temu postępująca utrata zębów i użytkowanie osiadających uzupełnień protetycznych, do których starsi pacjenci czasem trudno się adaptują. Osoby użytkujące protezy zębowe często modyfikują lub ograniczają wybór żywności. ${ }^{40}$ Skutki miejscowe i ogólnoustrojowe zaburzeń odżywiania mogą znacznie obniżyć komfort życia pacjenta. W celu eliminacji niedoborów żywieniowych w populacji osób starszych niezbędna jest edukacja i wydanie zrozumiałych dla pacjenta zaleceń dotyczących diety. Jest to grupa osób wymagających szczególnej opieki stomatologicznej i odpowiedniej motywacji. Zebranie wywiadu z zakresu sposobu odżywiania starszych pacjentów wydaje się być ważnym elementem diagnostyki lekarskiej. Ponadto należy podkreślić, że tkanki jamy ustnej są często pierwszymi, w których obserwuje się zmiany patologiczne w przebiegu chorób ogólnoustrojowych. ${ }^{41}$ Poprawa diety może wpływać na lepszą adaptację pacjenta do uzupełnień protetycznych, co istotnie zwiększy jego komfort życia. 


\section{References / Piśmiennictwo}

1. Wolańska W: Perspektywy starzenia się ludności polski do roku 2035. Prace naukowe Uniwersytetu Ekonomicznego we Wrocławiu, nr 38, 36-48.

2. Dragan A: Starzenie się społeczeństwa polskiego i jego skutki. Opracowania tematyczne OT-601. Kancelaria Senatu, Biuro Analiz i Dokumentacji, kwiecień 2011, s. 4-6.

3. Kozłowska A: Rola lekarza dentysty w rozpoznawaniu i leczeniu niedożywienia u pacjentów w podeszłym wieku. Magazyn Stomatologiczny 2016; 1: 58-60.

4. Barczak K, Palczewska-Komsa M, Buczkowska-Radlińska J: Fizjologiczne i patologiczne zmiany zachodzące w zębach i przyzębiu związane $\mathrm{z}$ wiekiem. Geriatria 2016; 10: 98-104.

5. Spiechowicz E: Protetyka stomatologiczna. PZWL, 2015; 14: 478-480.

6. Schimmel M, Katsoulis J, Genton L, Müller F: Masticatory function and nutrition in old age. Swiss dental journal SOO 2015; 125, 4: 449454.

7. Sheiham A, Steele J, Marcenes $W$ : The relationship among dental status, nutrient intake, and nutritional status in older people. J Dent Res 2001; 80: 408-413.

8. Skiba M, Kusa-Podkańska M, WysokińskaMiszczuk J: Wpływ stanu jamy ustnej na jakość życia osób w starszym wieku. Gerontologia Polska 2005; 13, 4: 250-254.

9. Jarosz $M$ : Normy żywienia dla populacji polskiej- nowelizacja. Instytut Żywności i Żywienia 2012; 28-29.

10. Kłosiewicz-Latoszek L: Otyłość jako problem społeczny, zdrowotny i leczniczy. Probl Hig Epidemiol 2010; 91, 3: 339-343.

11. Tayrol G, Burt B, Becker M, Genco R, Shlossman M, Knowler W, Pettitt D: Noninsulin dependent diabetes mellitus and alveolar bone loss progression over 2 years. J Periodontol 1998; 69, 1: 76-83.
12. Gandara B, Morton T: Objawy cukrzycy w jamie ustnej występujące poza przyzębiem: podstawowe informacje dla personelu medycznego. Diabetologia po Dyplomie 2012; 9, 1: 31-38.

13. Białokoz-Kalinowska I, Konstantynowicz J, Abramowicz P, Piotrowska-Jastrzębska J: Dieta w profilaktyce osteoporozy - zalecenia i kontrowersje. Pediatr Med Rodz 2013; 9, 4: 350-356.

14. Platta A: Rola żywienia w profilaktyce i leczeniu osteopenii i osteoporozy u kobiet. Zeszyty naukowe Akademii Morskiej w Gdyni 2014; 86: 16-28.

15. Bienkiewicz M, Bator E, Bronkowska M: Błonnik pokarmowy i jego znaczenie w profilaktyce zdrowotnej. Probl Hig Epidemiol 2015; 96, 1: 57-63.

16. Bogołowska-Stieblich A, Tałałaj M: Otyłość a choroby układu sercowo-naczyniowego. Postępy Nauk Medycznych 2013; 16, 5B, 1925.

17. Kantorowicz M, Chomyszyn-Gajewska $M$, Olszewska-Czyż I, Łazarz-Bartyzel K: Odżywianie a choroby przyzębia. Przegląd Lekarski 2013; 70, 1: 28-30.

18. Komperda J, Żurkowska J, Czapka M, Szczepańska M, Pierzak-Sominka J: Zespół metaboliczny - przegląd piśmiennictwa. Problemy Nauk Stosowanych 2014; 2: 149156.

19. Kłosiewicz-Latoszek L, Cybulska B: Cukier a ryzyko otyłości, cukrzycy i chorób sercowo-naczyniowych Cukier a ryzyko otyłości, cukrzycy i chorób sercowo-naczyniowych. Probl Hig Epidemiol 2011; 92, 2: 181-186.

20. Rychlik U, Marszatek A, Rychlik M: Choroby układu sercowo-naczyniowego a zapalenie przyzębia - problem pacjentów czy lekarzy? Journal of Laboratory Diagnostics 2013; 49, 3: 259-262.

21.Bartczyszyn M, Jaczewski M, Tomalik I: 
Evaluation of Removable Dentures' Hygiene Level and Oral Cavity Mucous Membrane Condition Among Long-Term Care Houses Inhabitants in Wroclaw. Dent Med Probl 2005; 42, 3: 477-481.

22. Cubera K: Stomatopatie protetyczne - definicja, etiologia, klasyfikacja oraz leczenie. Przegląd Lekarski 2013; 70, 11: 947-949.

23. Spiechowicz E: Stomatopatie protetyczne. PZWL 1993; 2: 21-25.

24. Lewandowski B, Stojatowski S, Wojnar J: Burning Mouth Syndrom: etiopathogenesis, diagnosis and treatment. Przegląd Medyczny Uniwersytetu Rzeszowskiego i Narodowego Instytutu Leków w Warszawie 2011; 1: 108114.

25. Yaacob H, Booi Cie l: Glossodynia and glossopyrosis- a discussion of the aetiology and management. Med J Malaysia 1981; 36, 3.

26. Krzysik M, Biernat J, Grajeta H: Wpływ wybranych składników odżywczych pożywienia na funkcjonowanie układu odpornościowego Cz. II. Immunomodulacyjne działanie witamin i pierwiastków śladowych na organizm człowiek. Adv Clin Exp Med 2007; 16, 1: 123-133.

27. Janda K, Kasprzak M, Wolska J: Witamina C - budowa, właściwości, funkcje i występowanie. Pom J Life Sci 2015; 61, 4: 419-425.

28. Wojtanowska-Rzytki M: Rola naturalnych antyoksydantów w profilaktyce chorób cywilizacyjnych. Farm Przegl Nauk 2009; 1: 23-27.

29. Śmierzchalska P, Chmielowiec M: Mapa usłonecznienia w Polsce. Projekt Czysta energia, 2015; $1-9$.

30. Grygiel-Górniak B, Puszczewicz M. Witamina $\mathrm{D}$ - nowe spojrzenie w medycynie i reumatologii. Postępy Hig Med Dosw 2014; 68: 359368.

31. Anuszewska E: Nowe spojrzenie na witaminę D. Gazeta Farmaceutyczna 2011; 32-35.

32. Ptudowski P, Karczmarewicz E, ChlebnaSokót D, Czech-Kowalska J, Dębski R,
Dobrzańska A, Franek E, Gtuszko P, Konstantynowicz $J$, Książyk $J$, KsiężopolskaOrlowska K, Lewiński A, Litwin M, Lorenc R, Łukaszkiewicz J, Marcinowska-Suchowierska E, Milewicz A, Misiorowski W, Nowicki M, Rozentryt P, Socha P, Solnica B, Szalecki $M$, Tałałaj $M$, Żmijewski M: Witamina D: Rekomendacje dawkowania w populacji osób zdrowych oraz w grupach ryzyka deficytów - wytyczne dla Europy Środkowej 2013 r. Standardy medyczne/Pediatria 2013, tom 10, 573-578.

33.Buczkowski K, Chlabicz S, Dytfeld J, Horst-Sikorska W, Jaroszyński A, Kardas P, Marcinkowska $M$, Siebert $M$, Tałałaj M: Wytyczne dla lekarzy rodzinnych dotyczące suplementacji witaminy D. Forum Medycyny Rodzinnej 2013, tom 7, nr 2, 55-58.

34. Barczak K, Szmidt M, Buczkowska-Radlińska $J$ : Funkcjonalność narządu żucia a poczucie depresji u pacjentów po 55. Roku życia zamieszkałych w środowisku rodzinnym i w domach pomocy społecznej. Psychiatr Pol 2016; 50, 5: 1027-1038.

35. Wawrzyniak A, Mincer-Chojnacka I, Kalicki B, Lipińska-Opatka A, Jobs K, Stelmasiak A: Plejotropowe działanie witamin D i K. Pediatr Med Rodz 2015; 11 (4): 374-381.

36. Fotda B: Zdrowotne trio - synergiczne działanie witamin D3, K2 oraz soli magnezowej. Harmonia 2015; 24-26.

37. Swora-Cwynar E, Marcinkowska E, Olejniczak M: Interakcje najczęściej stosowanych leków z żywnością. Piel Zdr Publ 2015; 5, 4: 427-439.

38. Diowksz A, Sucharzewska D, Ambroziak W: Rola błonnika pokarmowego w kształtowaniu cech funkcjonalnych ciasta i chleba bezglutenowego. Żywność. Nauka. Technologia. Jakość 2009; 2, 63, 83-93.

39. Jośko-Ochojska J, Spandel L, Brus R: Odwodnienie osób w podeszłym wieku jako problem zdrowia publicznego. Hygeia Public Health 2014; 49, 4: 712-717. 
40. Barczak K, Szmidt M, Buczkowska-Radlińska $J$ : Funkcjonalność narządu żucia a poczucie depresji u pacjentów po 55. roku życia zamieszkałych w środowisku rodzinnym i w domach pomocy społecznej. Psychiatr Pol 2016; 50, 5: 1027-1038.
41. Barone $J$ : Nutrition - phase one of the edentulous patient. J Prosth Dent 1978; 40, 2: 122-126.

Zaakceptowano do druku: 23.08.2018 r.

Adres autorów: 02-006 Warszawa, ul. Nowogrodzka 59. C Zarząd Główny PTS 2018. 